\title{
Reactor Device
}

National Cancer Institute

\section{Source}

National Cancer Institute. Reactor Device. NCI Thesaurus. Code C50131.

A vessel in which a chemical reaction takes place or an electronic device designed to add reactance to a circuit. 